\title{
Model of business interaction in corporate social responsibility strategy
}

\author{
Natalia Milchakova ${ }^{1,2^{*}}$, and Leonid Reshetnikov ${ }^{1}$ \\ ${ }^{1}$ Tyumen State University, 6 Volodarskogo Street, Tyumen, 625003, Russia \\ ${ }^{2}$ Surgut State University, 1 Lenina Street, Surgut, 628400, Russia
}

\begin{abstract}
In the current environment of increasing social and economic problems in Russian society, it is very important to increase the level of social responsibility of the business community and strengthen its institutional framework. The subject of the study is the organizational and economic relations that arise when corporations and economic entities interact in order to implement social responsibility. The paper begins with a presentation of the main theoretical approaches to defining models of corporate social responsibility of business. Elements of business social responsibility, a risk management system, and priority areas for forming a business social responsibility policy were identified. The novelty element of the research consists in building organizational and structural model of effective interaction between the management of the microsystem and mesosystem and the corporation on issues of social and economic development within the framework of the corporate social responsibility policy. The practical significance of the study is to determine the goals, objectives and principles of interaction between corporations and microsystem and mesosystems within the framework of corporate social responsibility. In addition, the areas and means of such interaction have been identified. The participation of the business community in the development of the social sphere should have a positive impact on maintaining social stability and economic balance.
\end{abstract}

\section{Introduction}

The purpose of the study is to substantiate the trends of interaction between the business community and the microsystem and mesosystem within the framework of implementing the corporate social responsibility strategy. The object of the study is corporate business that implements the principles of social responsibility in relations with internal and external stakeholders. The theoretical and methodological basis of the study was based on fundamental concepts and modern approaches presented in the works of domestic and foreign scientists (V.I. Barkhatov and D.A. Pletnev [1, 2], A.V. Vavilina [3], S.S. Galazova [4], O. E. Kuzina [5], M. V. Chernysheva [7], A. B. Carroll [6, 7], E. Freeman [8], A. Konrad [9], M. Langer [9], A. Martinnuzzi [9], M. Van. Marrewijk [10], A. Moutchnik [8], R. Steurer [9], D. Windsor [11, 12]).

\footnotetext{
*Corresponding author: mina@utmn.ru
} 


\section{Methods}

During the research, the authors used the following social and economic methods: analysis; study; generalization; comparison; logical and graphical.

The sources on which the provisions and conclusions of this paper were based were scientific works of foreign and domestic authors in the field of corporate social responsibility, which contributes to social, economic and environmentally sustainable development, and minimizes the negative impact of business on society.

\section{Results}

Nowadays, the concept of corporate social responsibility (CSR), which implies the active involvement of the company in the implementation of vital social projects, is widely spread in the business community.

Implementation of the corporate social responsibility policy of organizations has certain differences, which led to the allocation of a number of business CSR models. The main characteristics of foreign CSR models are presented in table 1.

Table 1. Main characteristics of foreign models of corporate social responsibility of business

\begin{tabular}{|c|c|}
\hline Model & Main characteristic \\
\hline European & $\begin{array}{l}\text { Region of application: originated and operates in the Nordic countries of the European } \\
\text { Community. } \\
\text { This model is not a universal line of operation of companies and, in most cases, is governed by the } \\
\text { laws, rules and regulations of the state in which the company operates. } \\
\text { However, some characteristics indicate the high social responsibility of the European model: } \\
\text { Maximum consideration of the nature of labor relations. } \\
\text { Additional professional insurance for the purpose of replacing wages. } \\
\text { Guaranteed minimum amount of pensions. } \\
\text { Three-level type of social protection: } \\
\text { The state - basic social guarantees. } \\
\text { Employer-social insurance. } \\
\text { Employee - personal insurance. }\end{array}$ \\
\hline British & $\begin{array}{c}\text { Region of application: operation is typical in Central European countries-Austria, France, } \\
\text { Germany, and the United Kingdom. } \\
\text { Extensive development of the independent consulting sector in the field of corporate social } \\
\text { responsibility. } \\
\text { The financial sector's interest in the social responsibility block. } \\
\text { The interest of mass media in the consecration of the social responsibility. } \\
\text { The operation of the business of education in a given block. } \\
\text { Involvement and participation of state bodies in the social responsibility of corporate structures. } \\
\text { Implementation of corporate social responsibility projects is formed on a voluntary basis. } \\
\text { Initiative on the part of the government to promote social and environmental responsibility } \\
\text { projects. } \\
\text { Active development of relationships with corporate employees. }\end{array}$ \\
\hline American & $\begin{array}{l}\text { Region of application: used in the United States, Latin America, and English-speaking countries in } \\
\text { Africa. } \\
\text { Active development of human potential, both in society as a whole and within companies. } \\
\text { Services and payments from corporate social funds give employees confidence in social security in } \\
\text { any circumstances. This increases employee loyalty to employers; } \\
\text { As a result, there is a strengthening of labor discipline, an increase in the quality of service and } \\
\text { products, and an increase in the company's competitiveness; } \\
\text { State incentives for business CSR are provided through tax incentives: taxable income is reduced } \\
\text { by the amount of charity expenses, income tax benefits are applied, and so on. }\end{array}$ \\
\hline Canadian & $\begin{array}{l}\text { Region of application: Canada } \\
\text { Focus on improving the quality and health-saving potential of the workplace; } \\
\text { Adapting hired employees to the company's corporate culture; } \\
\text { Value creation and its enhancement through the initiatives of its employees. } \\
\text { Evaluation of the overall performance of the company is based on the labor safety and health } \\
\text { status of the staff. }\end{array}$ \\
\hline
\end{tabular}




\begin{tabular}{|c|c|}
\hline Japanese & $\begin{array}{l}\text { Region of application: applicable only in Japan, as the Japanese are guided by their own codes of } \\
\text { ethics and share the standards of the European community. Only in } 2010 \text { they partially included } \\
\text { ISO } 26000 \\
\text { Ensuring gender equality; } \\
\text { Development of volunteerism - responsible behavior of citizens in relation to social problems; } \\
\text { Increasing responsibility for your country through volunteer programs; } \\
\text { Implementation of environmental programs; } \\
\text { The development of the industrial groups on the basis of honest and faithful partnerships. }\end{array}$ \\
\hline
\end{tabular}

Source [13-15].

For the Russian corporate system, it can be structured elements of business social responsibility into two categories: current projects and prospective projects. Here is a list of current projects that are well-known and well-developed by Russian corporations:

- financing of local projects that are directly or indirectly related to the company's activities;

- support of educational programs of the country's leading Universities with subsequent hiring of graduates;

- availability of a social package that includes payment for sports and VMI, the possibility of preferential lending in partner banks, corporate pension provision;

- implementation of the policy of tolerance and interaction with formal and informal territorial communities that provide social support to various groups of people in need;

- implementation of environmental policy, participation of the company's representative in thematic events;

- creation of a cross-functional committee to control corruption;

Corporations do not just declare social responsibility, but also practice real investments in the implementation of specific social projects. Companies are increasingly paying attention to non-financial sources of capitalization growth and, first of all, to the formation and development of human capital. The main areas of investment are still social programs aimed at developing the company's staff, protecting health and creating safe working conditions. Expenses on social responsibility is no longer perceived by companies solely as a "one-sided" charity, but as a mutually beneficial partnership with their employees. Financing of social programs for the development of a specific employee of the company is increasingly a priority, since it brings a specific production effect.

In the case of organizational support of social responsibility in companies, the signs of "organizational training" prevail, as a step-by-step development of the entire system of business social responsibility, and the accumulation of certain knowledge and competencies by their employees. Corporations usually finance social programs in which the share of government investment is not quantitatively adequate. There are still no clear boundaries between charity and social investment. Business structures are still not fully aware of the real economic benefits of socially responsible activities. The vast majority of companies, about $60 \%$, hope to receive image-based dividends in the first place, while the rest consider the implemented social programs as the shortest way to improve the company's business reputation. When analyzing the effectiveness of implemented social projects, most companies still evaluate their effectiveness by the amount of funding, rather than by the effect achieved. Currently, only $56 \%$ of companies evaluate the effectiveness of social investments. $17 \%$ of enterprises do not organize performance assessment at all [16].

It is necessary to review the prerequisites and conditions for the formation of a business social responsibility policy, clearly highlighting the regional and federal levels of interaction with stakeholders. So, at the federal level, priority areas should be:

- allocation of the function of formulating national priorities and regulating business CSR and non-financial reporting at the level of the Federal Minister (without using any new administrative forms);

- holding annual forums on social and environmental responsibility of business and 
forms of its interaction with the state;

- development and dissemination of regular government public communications (statements) on the development of the system of social and environmental responsibility of business;

- development by leading business associations (Russian Union of Industrialists and entrepreneurs, Delovaya Rossiya and OPORA), as well as industry associations of manufacturers, of recommendations for the implementation of international standards of management and reporting in the field of sustainable development and ecology on a voluntary basis;

- budget financing and tender distribution of projects in the field of business CSR, sustainable development and eco-reporting among specialized non-profit organization.

Risk management systems play an important role in shaping the business CSR model. According to many foreign experts, they are one of the most problematic aspects of corporate governance at the company level in Russia. At the same time, the set of risks covered by CSR has been expanding recently. Among the most significant of these are the risks associated with increasing expectations of stakeholders. For example, in many regions and countries, local communities have expectations that corporations should make a number of voluntary commitments to ensure the social well-being of these communities. Another example is that representatives of the Russian state authorities have expectations that domestic companies should refuse to use offshore schemes in order to minimize tax deductions and withdraw capital abroad. If such risks are not properly managed, they can have a strong negative impact on the company's operations. Therefore, the formation of effective risk management systems and their continuous improvement is the most important task, the solution of which will have a positive impact on many aspects of corporate management, including CSR.

In addition to these risks, the effectiveness of the business social responsibility policy may be negatively affected by such risks:

- reputational risks - reduced revenue due to negative public opinion and reduced confidence in the company;

- social and labor risks - decrease in business efficiency as a result of the outflow of qualified personnel, as well as the increase in social tension in the region of presence due to criticism of management decisions regarding personnel and social infrastructure facilities;

- corporate management risks - the threat of reducing the company's value as a result of insufficient quality of management bodies, lack of clear procedures for relations between shareholders and management, and transparency in information disclosure;

- risks of legal regulation (changes in legislation) - changes in the requirements for conducting core business on a wide range of issues: from licensing and taxation to the relationship between the employer and the employee;

- political risks - a set of political, administrative, and national events that can lead to financial and other losses of the company.

The main tool for managing CSR business risks is a constant dialogue with the main stakeholders, which helps to identify conflicts of interest and timely neutralize risks.

As for working with risks in the practice of Russian companies, no single policy has been formed, and each company defines a set of risks and tools for minimizing them individually, taking into account the current situation at the macro and micro levels.

We believe that an effective corporate social responsibility model should take into account the interests of all stakeholders. The model parameters are shown in figure 1. 


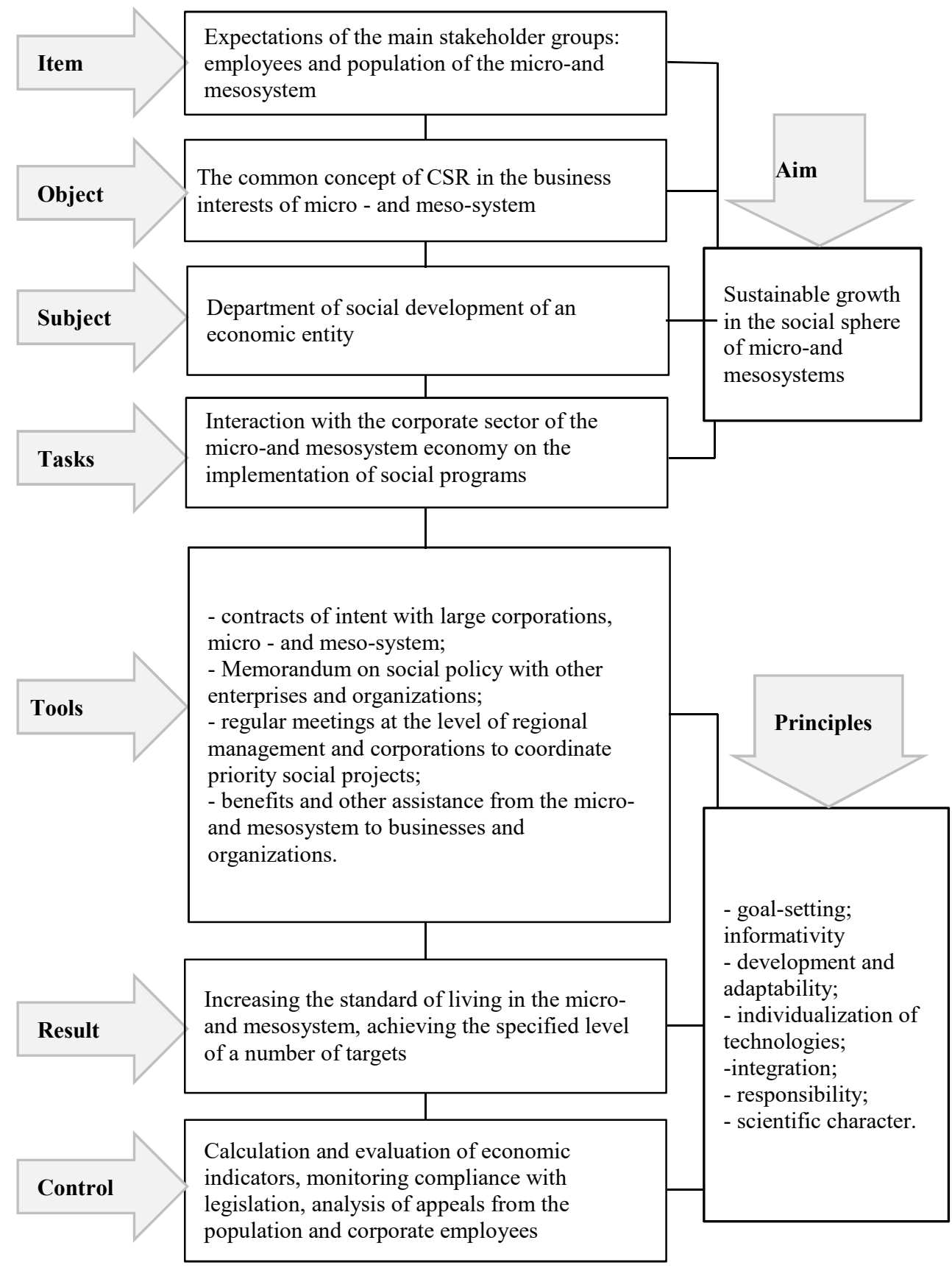

Fig. 1. The main parameters of the model of interaction between the region and the corporation in the framework of the CSR strategy

Thus, the CSR business model, focused on the development of the social sphere, sets as planned results the achievement of target values of a number of indicators and the overall growth of living standards. 


\section{Discussion}

Nowadays, in Russian practice, companies participate in the implementation of micro - and meso-level social programs that are developed by an economic entity taking into account federal programs. Naturally, corporations should take this into account when forming their social programs.

Thus, the first key area of the corporate social responsibility model is information openness. The publication of social (non-financial) reports has a positive impact on the attitude of stakeholders to the corporation.

The next area of business social responsibility should be the revision of the procedure for interaction with staff. Loyalty to the company has a significant impact on the willingness of employees to make every effort to achieve common goals and take on additional functions and responsibilities, as well as on the quality of work performed and creative approach to solving professional tasks.

We will highlight the following areas of work with the staff:

- rewarding employees for their achievements in work and placing this information in internal corporate media

- involvement of employees in discussion of work results, current issues, and search for solutions;

- development of a program for employee career planning and succession planning;

- development of a mentoring system;

- creation of competitions on rationalization proposals and improvement of work;

- posting information about the company's short - term and long-term development prospects on the corporate website;

- informal round table discussions, meetings, meetings with management;

- organization of forums on the corporate website.

Thus, improving the efficiency of personnel work is also one of the key priorities of the corporate social responsibility model.

The next priority of the CSR model should be interaction with the public of the microand mesosystem on the implementation of social projects. When choosing social investment directions, the company can follow the following rules:

- investments should contribute to achieving the company's corporate strategic goals;

- should be realistic in terms of financial and other resources;

- addressed to those groups of the population that do not receive it from other, including budgetary, sources;

- contribute to the success of the economic strategy.

Therefore, the approval of social projects should be made only after the analysis of this project within the company and in interaction with members of the public.

In addition to the priorities of social responsibility of business, it is necessary to continue implementing the policy of environmental responsibility.

In addition, at the administrative level, it is possible to:

- subsidizing the implementation of procedures and measures aimed at increasing the social responsibility of regional companies;

- financing and organizational support for seminars on exchange of experience, training seminars in the field of management, including in the social sphere;

- providing methodological assistance to regional companies in improving their interactions with stakeholder groups;

- financing of training of specialists.

Planning and implementation of measures aimed at promoting social responsibility in 
the micro-and meta-system must be made by clear and transparent rules under the policy support companies in the field of social responsibility (for example, regulations on the conduct of competitions, rules of allocation of budgetary funds, etc.). Since there are no general recommendations for developing such rules, the business social responsibility model must adapt to the territorial, national, social and economic specifics of the system.

The most important element of the CSR model on the part of the region's management is monitoring. Therefore, at the corporation - authority" level, feedback procedures are mandatory, consisting in monitoring compliance with the rules of agreements. Practice shows that control indicators should include not only the figures of official (financial and statistical) reports, but also the results of various surveys of employees and the population (questionnaires, in-depth interviews, focus groups), adapted to the specifics of the enterprise, the social situation at the enterprise and in the region.

The developed model of interaction, using the example of a mesosystem and a corporation in the context of corporate social responsibility, is presented in figure 2.

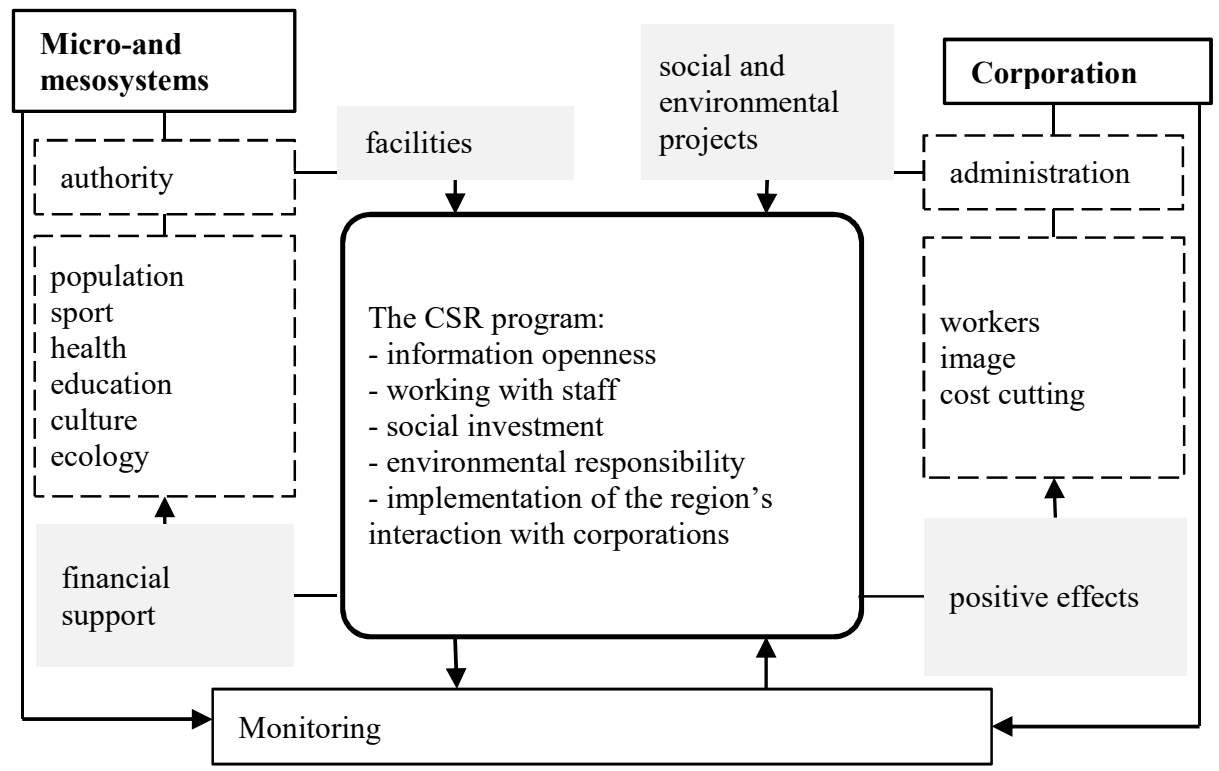

Fig. 2. Model of interaction between micro-and mesosystems and corporations in the CSR part

Thus, the generated model reflects all the main aspects of interaction between the management of corporations and government bodies of the subject. It is important to note that the model assumes joint efforts of the subject and business to achieve the goal-growth in the social sphere of the subject. We will also highlight the joint monitoring of the implementation of the Program of interaction in the CSR part.

\section{Conclusions}

This model is applicable to any micro-and mesosystem, its individual parameters may differ: the amount of benefits provided to business, types and directions of financial support from business, and a set of criteria for evaluating the effectiveness of interaction. The program of interaction between the authorities can be based on the conclusion of a special memorandum. This memorandum sets out business CSR targets for the development of the social sphere. On the basis of this document, the regional leadership will be able to make proposals quickly for the redistribution of business funds between different objects of social 
investment. At the same time, both the regional authorities and business representatives will be able to control the implementation of the memorandum.

\section{References}

1. D.A. Pletnev, V.I. Barhatov Procedia - Social and Behavioral Sciences, 221, 185-193 (2016).

2. V. Barhatov, D. Pletnev, E. Nikolaeva, Procedia-Social and Behavioral Sciences, 124, 521-527 (2014). DOI: 10.1016/j.sbspro.2014.02.515

3. A.V. Vavilina, T.V. Komarova et al., Liderstvo i menedzhment, 6(4), 425-436 2019. (doi: 10.18334/lim.6.4.41313)

4. S.S. Galazova, Terra economicus, 16(3), 77-86 (2018). doi: 10.23683/2073-66062018-16-3-77-86)

5. O.E. Kuzina, M.V. Chernysheva, Monitoring of Public Opinion: Economic and Social Changes, 4. 154-165 (2015). doi: 10.14515/monitoring.2015.4.08

6. A.B. Carroll, A Three-Dimensional Conceptual Model of Corporate Performance, Academy of Management Review 4(4), 497-505 (1979).

7. A.B. Carroll, Business and Society, 38(3), 268-295 (1999)

8. E. Freeman, A. Moutchnik, Stakeholder management and CSR: questions and answers. 21, 5-9 (2013). https://doi.org/10.1007/s00550-013-0266-3

9. R. Steurer, M. Langer, A. Konrad, A. Martinnuzzi, Journal of Business Ethics, 61(3), 263-281 (2005).

10. M. Van. Marrewijk, Journal of Business Ethics, 44(2-3), 95-105 (2003).

11. D. Windsor, Journal of Management Studies, 43(1), 93-114 (2006).

12. D. Windsor, The International Journal of Organizational Analysis, 9(3), 225-256 (2001).

13. Management Models for Corporate Social Responsibility, doi: 10.1007 / 3-540-332472

14. A Study on the Models for Corporate Social Responsibility of Small and Medium Enterprises. doi: 10.1016/j.phpro.2012.03.108

15. The Impact of Corporate Social Responsibility on Long-Term Relationships in the Business-to-Business Market. doi:10.3390/su11195377

16. E.V. Pechkina, Interaktivnaja nauka, 2(12), 219-221 (2017). doi:10.21661/r-117619 